\title{
Overview of the translocation of rupestrian ferruginous fields of Capão Xavier mine to the Serra do Rola Moça State Park, Minas Gerais - Brazil
}

\author{
Alessandra F. Fernandes ${ }^{1}$, Ana C. Maia ${ }^{2}$, Juan F. S. Monteiro ${ }^{3}$, João N. Condé ${ }^{4}$, and Mauro Martins ${ }^{4}$ \\ ${ }^{1}$ Centre for Functional Ecology, Department of Life Sciences, University of Coimbra, \\ Calçada Martim de Freitas, 3000-456, Coimbra, Portugal \\ ${ }^{2}$ Faculdade Maria Thereza, Av. Visconde do Rio Branco, 869, São Domingos, Niterói, RJ, Brazil \\ ${ }^{3}$ Universidade Federal de São João del Rei, Campus Dom Bosco, 74, Fábricas, São João del Rei, Brazil \\ ${ }^{4}$ Instituto Federal de Educação, Ciência e Tecnologia do Sudeste de \\ Minas Gerais, Lindo Vale, Rio Pomba, Brazil
}

Correspondence to: Alessandra F. Fernandes (alessandra.fernandes@ifsudestemg.edu.br)

Received: 30 August 2015 - Revised: 13 April 2016 - Accepted: 18 April 2016 - Published: 28 April 2016

\begin{abstract}
The identification of priority areas for the conservation of Brazilian biodiversity and the application of prompt practical measures are essential for an effective environmental management. The Serra do Rola Moça State Park, located in the Iron Quadrangle, on the southern end of the Espinhaço Range, in Minas Gerais, Brazil, is a region that is home to the rupestrian ferruginous fields or canga vegetation, a still poorly studied vegetation, rich in endemic, rare, and endangered species. The aim of this work is to contribute to the understanding of the rupestrian ferruginous fields, providing a floristic analysis, a quantification of species richness, and survival (vegetative growth in laboratory conditions, the production of nursery saplings and the management of the areas) of translocated species from the Capão Xavier mine pit to the park. The species presented belong mainly to the Asteraceae, Rubiaceae, Myrtaceae, Velloziaceae, Bromeliaceae, Orchidaceae, and Solanaceae families. Nowadays, the surrounding area of the administrative headquarters of the park shelters around 10000 individuals and about 15000 in other areas of the park. In the rescue and transposition of saplings, there was a loss of less than $31.29 \%$ of the individuals directly introduced to the planting area, while only $10 \%$ of the saplings grown in the nursery were lost. The knowledge acquired about the viability of the studied species, their spread, and conservation indicates the possibility of nursery breeding of some of the native species and their use in the recovery of areas in mining regions.
\end{abstract}

1

\section{Introduction}

The Cerrado (savannah) occupies about $22 \%$ of Brazil's national territory. It is an environment with mosaic vegetation shaped by topography, lithology, climate, and altitude. In it we can find the rupestrian ferruginous fields, known as canga vegetation, above $1200 \mathrm{~m}$ (Dorr II, 1969; Castro, 2008), in what is known as the Iron Quadrangle in Minas Gerais. It covers an area of approximately $7200 \mathrm{~km}^{2}$, forming the southern end of the Espinhaço Range, considered to be the centre of diversity of families like Eriocaulaceae and
Velloziacea, with $90 \%$ of their species being endemic to this region (Giulietti et al., 2005).

The vegetation is also home to rare species (sensu Giulietti et al., 2009) with high alpha and beta diversity (Viana and Lombardi, 2007; Jacobi and Carmo, 2012). Due to their distribution in restricted areas, and because they cover up important iron ore deposits subjected to intensive mining activities, these ecosystems are amongst the most threatened in Brazil.

The Serra do Rola Moça State Park (SRMSP) is considered a Conservation Unit of Integral Protection by Law $9985 / 2000$, which allows the creation of partnerships be- 

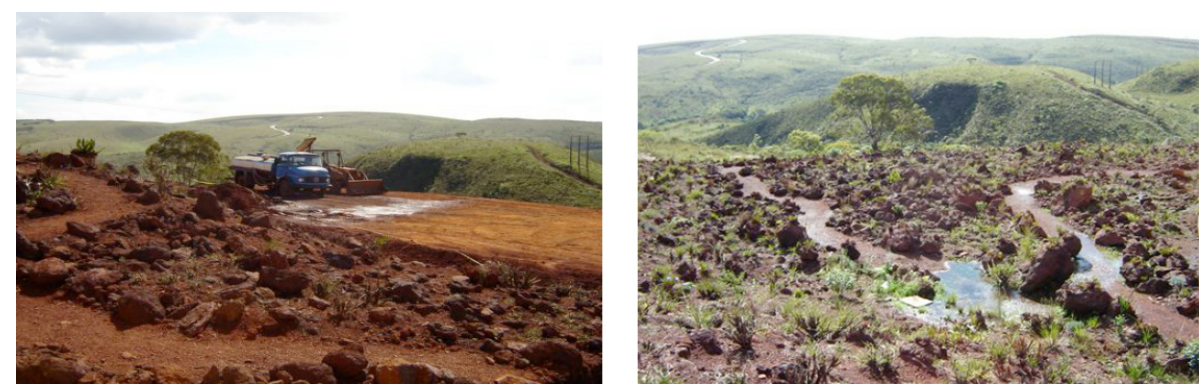

Figure 1. Surrounding area of the park headquarters before and after the canga vegetation translocation. Photo credit: A. F. Fernandes.
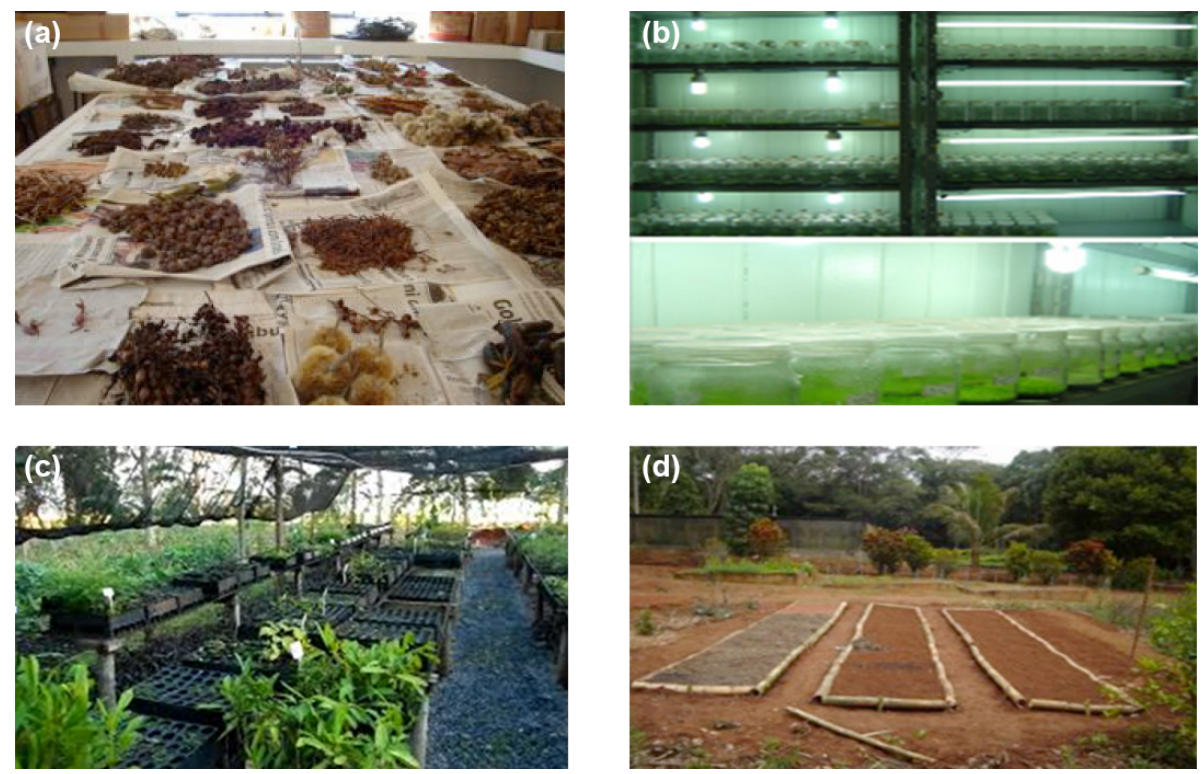

Figure 2. Seeds (a), greenhouse saplings (b), nursery of canga vegetation species (c), and outdoor beds (d). Photo credit: A. F. Fernandes.

tween the managing agency of the park and mining companies. For this study, a partnership with the VALE mining company was created before the beginning of mining exploration.

This work aimed to provide a list of the species translocated from the Capão Xavier mine pit to the SRMSP, and to analyse its floristic composition and the survival of the translocated species.

\section{Materials and methods}

Created in 1994, the SRMSP has an area of 3942 ha, covered with Cerrado, Atlantic Forest, altitude fields, and canga vegetation species. The climate is seasonal, with two distinct seasons: dry and wet. The average annual precipitation is $1500 \mathrm{~mm}$, with large intra-regional variations.

Initially, we carried out the transposition of the canga vegetation species from Capão Xavier mine to the park (vegetation rescue). To that end, it was necessary to transport the iron ore stones with the root systems of the plants inserted in them by truck and tractor. We used an area of 0.61 ha (around the park headquarters) to recreate the same environment of the mine canga vegetation with about $4500 \mathrm{t}$ of iron ore substrate (topsoil).The species were transplanted and managed, and currently the area is home to around 10000 canga vegetation individuals (Fig. 1).

In order to do that, we conducted floristic surveys to quantify plant richness, and we studied plant germination and recruitment both in laboratory conditions and in restored areas in the field. The species were classified in families recognized by the Angiosperm Phylogeny Group II system (APG, 2003).

The seeds of the species found were collected manually from randomly selected individuals of the same population ( $n>50$ individuals per species) for a year.

We used the seeds for cultivation in a greenhouse and nursery of saplings. We sowed some seeds directly in a prepared substrate, which was enclosed in black polyethylene bags ( $8 \mathrm{~cm}$ diameter and $20 \mathrm{~cm}$ deep), one seed per bag. The substrate used for growth of seedlings was composed of equal parts of subsurface soil, peat bog, and an organic compound 
Table 1. Main species planted in Serra do Rola Moça State Park with absolute percentage of survival amount and degree of conservation (system of categories and criteria of IUCN - Red Book of Flora of Brazil - Rare Plants Cerrado, Martinelli et al., 2014).

\begin{tabular}{|c|c|c|c|}
\hline Family & Species & $\begin{array}{c}\% \\
\text { Survival }\end{array}$ & $\begin{array}{c}\text { Degree of } \\
\text { conservation }\end{array}$ \\
\hline \multirow{4}{*}{ Asteraceae } & Baccharis reticularia & 78 & not threatened \\
\hline & $\begin{array}{l}\text { Chromolaena } \\
\text { multiflosculosa }\end{array}$ & 66 & not threatened \\
\hline & Lychnophora pinaster & 91 & near threatened \\
\hline & Baccharis serrulata & 87 & not threatened \\
\hline \multirow{2}{*}{ Bromeliaceae } & Aechmea bromeliifolia & 60 & not threatened \\
\hline & Billbergia amoena & 78 & not threatened \\
\hline Fabaceae & Mimosa calodendron & 95 & not threatened \\
\hline \multirow{8}{*}{ Orchidaceae } & Bifrenaria tyrianthina & 48 & not threatened \\
\hline & Bulbophyllum weddelli & 35 & threatened \\
\hline & Epidendrum secundum & 33 & threatened \\
\hline & Laelia caulescens & 89 & threatened \\
\hline & Oncidium warmingii & 70 & not threatened \\
\hline & Pleurothallis teres & 77 & threatened \\
\hline & $\begin{array}{l}\text { Prosthechea } \\
\text { pachysepala }\end{array}$ & 65 & threatened \\
\hline & Zygopetallum mackayii & 22 & threatened \\
\hline \multirow{5}{*}{ Velloziaceae } & Vellozia albiflora & 89 & near threatened \\
\hline & Vellozia caruncularis & 96 & not threatened \\
\hline & Vellozia compacta & 96 & not threatened \\
\hline & Vellozia graminea & 78 & threatened \\
\hline & Vellozia resinosa & 66 & threatened \\
\hline
\end{tabular}

(consisting of equine manure hardened with sawdust, in proportion of $1: 1)$. To correct acidity and for nutritional enrichment, we added $2 \mathrm{~L}$ of $\mathrm{CaCO}_{3}$ and $1 \mathrm{~L}$ of NPK $(4: 14: 8)$ in $360 \mathrm{~L}$ of substrate. The resulting compound was completely mixed to homogeneity and used for filling the containers. For 7 months, the saplings grew in a nursery at $50 \%$ shading and irrigated by micro sprinklers, for $15 \mathrm{~min}$, three times a day, totalling $17.5 \mathrm{~mm}$ of water per day. Subsequently, we moved the saplings to the open, with gradual reduction of water supply in order to adapt the seedlings before being planted in their final location in georeferenced areas defined in the Management Plan of the park.

Other species were sown in agar defined as medium and placed in a greenhouse at $25^{\circ} \mathrm{C}$. Emerging seedlings were counted, weekly, for the first 60 days and, after that period, every 2 weeks. Seedlings were transplanted to tubes and placed in nurseries and then in outdoor beds (Fig. 2). Planting took place with saplings aged 7 months approximately, amounting to about 5000 individuals.
Canga vegetation of Capão Xavier mine

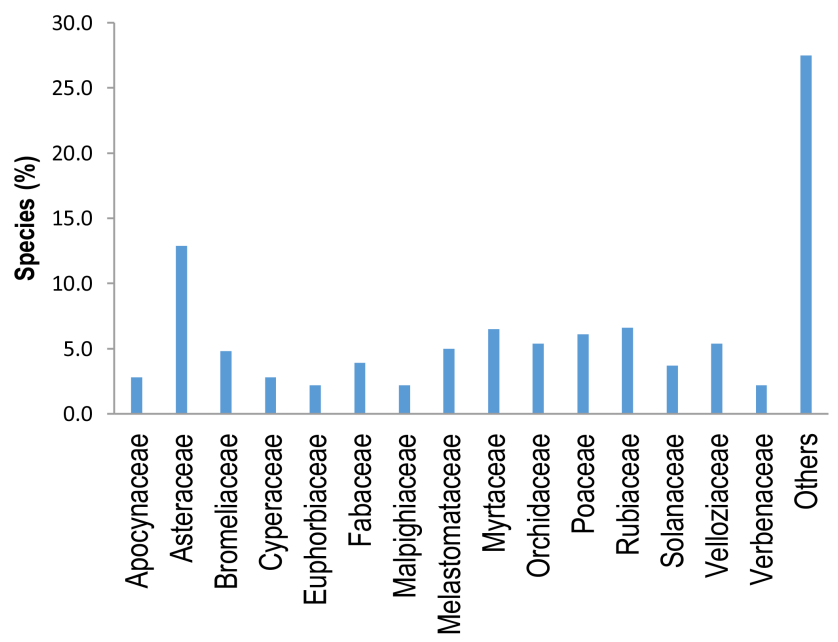

Figure 3. The 15 families of Angiosperms with higher richness of species found in canga vegetation in Capão Xavier mine. The numbers represent the percentage contribution of each family to species richness.

In order to monitor the saplings, we randomly selected 50 individuals of each species from a total of 20 species (Table 1). These individuals were tagged and monitored for 18 months from planting. For all tagged individuals, we evaluated the survival rate in the same month of planting. The survival rate was calculated as the percentage of the individuals alive at the end of monitoring considering all planted individuals.

\section{Results and discussion}

In this study, we observed that the species of the families Orchidaceae $(5.4 \%)$, Velloziaceae $(5.4 \%)$, Bromeliaceae $(4.8 \%)$, Fabaceae $(3.9 \%)$, Solanaceae $(3.7 \%)$ are well represented in canga vegetation but the highest proportion is from species of the families Asteraceae (12.9\%), Rubiaceae (6.6\%), and Myrtaceae (6.5\%) (Fig. 3).

The family Velloziaceae is the symbol of the park and is significantly represented by Vellozia caruncularis, V. compacta, and V. graminea.

All the species removed from the mine area are typical of rupestrian ferruginous fields sensu lato, like Vellozia compacta Mart. (Velloziaceae), Tibouchina multiflora Cogn. (Melastomataceae), Lychnophora pinaster Mart. (Asteraceae), the last of which stands out for its medicinal value and for being considered vulnerable. Some species are endemic to rupestrian ferruginous fields, like Arthrocereus glaziovii (Taylor and Zappi, 2004), Dyckia consimilis, and Vriesea minarum (Versieux, 2005). We can also find the families Amaryllidaceae, Apiaceae, Araceae, Arecaceae, Cactaceae, Clusiaceae, Cyperaceae, Euphorbiacea, Fabaceae, Iri- 
daceae, Lythraceae, Malpighiaceae, Piperaceae, and Verbenaceae corresponding to $27.5 \%$ of total species richness.

Preliminarily, in the rescue and transposition (direct planting) of saplings we observed the loss of less than half $(31.29 \%)$ of the individuals that were directly introduced to the planting area. As for saplings grown in nursery, the loss was only $10 \%$. Regarding the vegetative growth of the canga vegetation species (greenhouse), there was poor performance on seed germination in vitro (ranging from 2 to $10 \%$ depending on species) and a high cost of production, making it not feasible to use, at first glance.

Families Eriocaulaceae and Xyridaceae are rare in canga vegetation, probably due to the lack of sandy soils or the absence of marshy environments, which reduce the availability of a suitable habitat to the establishment of those families in canga vegetation (Viana and Lombardi, 2007). The great variety of species used in the planting belongs to the families Orchidaceae, Velloziaceae, Bromeliaceae, Asteraceae, and Fabaceae. Regarding the number of introduced individuals, most of them belong to the families Bromeliaceae, Velloziaceae, and Orchidaceae. The bromeliad Aechmea bromeliifolia, the "canela de ema" Vellozia compacta, and the orchid Epidendrum secundum were the most significant in number of individuals planted.

\section{Conclusions}

From the results obtained in the present study, we can conclude that, as most species involved are restricted to rocky ferriferous environments, measures that aim to harmonize the extraction of iron ore with the preservation of this vegetation are very important and the demand for rescue and reproduction of these species becomes clear, through the use of several strategies in order to achieve the conservation of biodiversity of this type of vegetation.

Since the plants comprise species that are rare, endangered, endemic, and difficult to reproduce, we conclude that the passage through nurseries is mandatory to save as many individuals as possible (Santos, 2008).

Environments with translocated species like this one are non-existent and have never been studied before. For that reason, it is not yet possible to know whether there will be longterm in situ conservation. Further studies are needed on the different forms of germplasm collection: through saplings, seeds, seedlings, stakes, or bank of seeds contained in the topsoil. The characteristics of each family will define the ideal type of ex situ rescue and conservation to be adopted.
Acknowledgements. A. F. Fernandes acknowledges the doctoral scholarship supported by CNPq/CAPES - Programa Ciência sem Fronteiras CsF (6057/13-6) and authorized retirement by IF SUDESTE MG (no. 476, 17 May 2013).

Edited by: J. Stadler

Reviewed by: two anonymous referees

\section{References}

APG II - Angiosperm Phylogeny Group, An update of the Angiosperm Phylogeny Group classification for the orders and families of flowering plants: APG II, Bot. J. Linn. Soc., 141, 399436, 2003.

Castro, P. T. A.: Cangas: a influência da geodiversidade na biodiversidade, in: Simpósio Afloramentos Ferruginosos no Quadrilátero Ferrífero: Biodiversidade, Conservação e Perspectivas de Sustentabilidade, Belo Horizonte, Brazil, 30-51, 2008.

Dorr II, J. V. N.: Physiographic, stratigraphic and structural development of QuadriláteroFerrífero, Minas Gerais, Brazil, US Geological Survey, Prof. Paper, 641-A, Washington, USA, 110 pp., 1969.

Giulietti, A. M., Harley, R. M., Queiroz, L. P., Wanderley, M. G. L., and Van den Berg, C.: Biodiversidade e conservação das plantas no Brasil, Megadiversidade, 1, 52-61, 2005.

Giulietti, A. M., Rapini, A., Andrade, M. J. G, Queiroz, L. P., and Silva, J. M. C.: Plantas raras do Brasil, Conservation International, Belo Horizonte, Brazil, 496 pp., 2009.

Jacobi, C. M. and Carmo, F. F.: Diversidade florística nas Cangas do Quadrilátero Ferrífero. Ed. IDM, Belo Horizonte, Brazil, 240 pp., 2012.

Martinelli, G., Messina T., and Santos Filho, L.: Livro vermelho da flora do Brasil - Plantas raras do Cerrado/Organizadores tradução David Straker, Chris Hieatt. 1. ed., Rio de Janeiro: Andrea Jakobsson: Instituto de Pesquisas Jardim Botânico do Rio de Janeiro: CNCFlora, 322 pp., 2014.

Santos, F. M. G.: Comportamento germinativo de espécies do gênero Stachytarpheta Vahl, (Verbenaceae) ocorrentes nos campos rupestres da Cadeia do Espinhaço em Minas Gerais, Dissertação (Mestrado em Biologia Vegetal), ICB, Universidade Federal de Minas Gerais, Belo Horizonte, Brazil, 2008.

Taylor, N. P. and Zappi, D. C.: Cacti of Eastern Brazil, Royal Botanical Gardens, Kew, UK, 499 pp., 2004.

Versieux, L. M.: Bromeliáceas de Minas Gerais: catálogo, distribuição geográfica e conservação, Dissertação de Mestrado, UFRJ, Rio de Janeiro, Brasil, 234 pp., 2005.

Viana, P. L. and Lombardi, J. A.: Florística e caracterização dos campos rupestres sobre canga na Serra da Calçada, Minas Gerais, Brasil, Rodriguésia, 58, 159-177, 2007. 